\title{
REVIEWS
}

\section{MicroRNA: from fundamental research to their application}

\author{
T. V. Shirina, M. T. Bobrovskaya, E. A. Kozlov \\ Institute of molecular biology and genetics NAS of Ukraine \\ Academicain Zabolotnog str., 150, Kyiv, 03680 Ukraine \\ E.mail: kozlov@imbig.org.ua
}

MicroRNAs (miRs) are small non-protein-encoding RNAs of 20-30 nucleotides long. In eukaryotic cells miRs play the role of bioregulators of gene expression through the mechanisms of translation repression/modulation. Here we both familiarize the readers with miRs biogenesis, functioning mechanisms, and strategy of their discovery and present the list of biological processes, regulated by miRs. We also list the publications, dedicated to miRs role in human pathologies (carcinogenesis in particular) and their application for marking, prevention, diagnostics, and therapy of cancer.

Key words: microRNA, biogenesis, expression profile, bioinformatic, microRNA-prediction, bioregulation, carcinogenesis, therapy.

Introduction. The beginning of the century was renowned for one of the greatest discoveries, which could be compared with the discovery of double stranded DNA by James Watson and Francis Crick or with the discovery of reverse transcription by Howard Temin and David Baltimore. This discovery can be considered to be the revolutionary one as it not only supplements our ideas on growth regulation and differentiation of cells and widens the ideas on various cell metabolism and the processes of development of the organism but also helps to perceive the paradigm of medical treatment of various diseases, especially cancer diseases and diseases of development, based on the aforementioned knowledge. This is the discovery of minor RNA molecules, capable of inducing RNA-interference.

Two groups of minor interfering $R N A$. The two groups differ in biogenesis and in the role they play in

(C) T. V. SHIRINA, M. T. BOBROVSKAYA, E. A. KOZLOV, 2007 organisms, yet have many common features in the mechanisms of their functioning. The class of minor RNAs is represented by small non-coding RNAs (snRNAs), 20-30 nucleotides long. Functioning of snRNA results in silencing of gene expression at transcriptional and post-transcriptional levels due to complementary interactions as a part of ribonucleoprotein (RNP) effector complexes with their DNA- (level of transcription) and RNA- (level of translation) targets [1]. In this paper we describe only the second (from the point of view of chronology of discovery) group of snRNAs, i.e. microRNAs, miRNAs, or miRs.

However, prior to discussing miRs we need to mention the first group of snRNAs - small interfering RNA or siRNAs. This group is represented by double-stranded spiral RNA, 22 and 28-30 nucleotides long which are due to occur after splitting of large double-stranded RNA by RNAase III endonuclease, also known as Dicer $[2,3]$. According to the source of dou- 
ble-stranded RNA in the cell, siRNAs can be classified into two sub-groups, which are specific for different biological effect and different functions. Unlike double-stranded RNA, which are delivered into the cell by viruses and transgenes or occur after aberrant synthesis of RNA, "diced" siRNAs of 22 nucleotides long function as the mechanism of cell protection from non-specific allogenic RNA, and present a sort of immune response at the level of RNA [2]. If double-stranded RNA is synthesised in the cell in the natural way from genome region, which includes centromeres, transposons, telomeres or repeats, "diced" siRNAs of 28-30 nucleotides long take an active part in the epigenetic processes, resulting in silencing of genes at the level of transcription [4].

That is about all we wanted to mention in regard to the first group of snRNAs - siRNAs - to emphasize the principal differences from the second group of small interfering RNA - miRs.

Different aspects of genome organisation, biogenesis, regulation of transcription, functioning of miRNAs and their role in the regulation of differentiation and cell growth, as well as the development of organism and various cell processes are the subject of reviews [5-7]. Hence, the aim of current review is to turn the attention of molecular biologists onto these tiny bioregulators, which, apparently, take part in all cell processes.

Distribution and localisation of miRs genes. The principal difference of miRs is their endogenic origin, i.e. cell genomes contain miR genes. The latter were discovered in almost all representatives of eukaryotes and in large DNA-containing viruses (except for RNA-containing human immunodeficiency virus (HIV)) [8], genome of which is incorporated into the host genome. Usually miR genes are localized in the intergenic region of encoding chains as single genes or their clusters [9]. They are located in the intron regions of encoding genes (intronic miRs) $[10,11]$ and in transposon elements [12].

miRs biogenesis. There is hardly any information on the initiation and regulation of transcription of primary transcript (pri-miR) for miR as well as on the factors, regulating expression of miRs. Regulation of miR-155 expression was shown in Burkitt's lymphoma to take place at two levels: i) level of transcription, in- volving proteinkinase $\mathrm{C}$ and nuclear kappa $\mathrm{B}$ factor and ii) level of processing via yet undiscovered mechanism [13].

Lee et al. [14] identified numerous regulatory elements, located in 5'-positions towards miRs genes, known to be significant for transcriptional and post-transcriptional regulation of expression of miRs. Fukao et al. [15] revealed that miRs are predominantly controlled by unique cis-regulatory elements, which co-develop with miRs sequences. These data reveal the possible participation of well-characterized transcription factors, protein-encoding genes, in the expression of miRs genes. miRs along with transcription factors make the regulatory networking, controlling thousands of genes, possibly including expression of miRs genes [16]. The latter were shown to be co-expressed with their mRNA-targets. At the same time mammalians were demonstrated to have two classes of cyclic expression co-regulation of miRs and their targets with positive and negative feedback [17], which involves miRs as stabilizing and destabilizing factors in the dynamics of the gene expression [18]. Apparently, transcriptional regulation of miRs gene expression is controlled via some epigenetic mechanisms [19-21]. The mechanisms, based on single nucleotide polymorphism [22-24] and $A \rightarrow I-$-editing of the predecessors and mature miRs [25-29] can be possibly included to the list of mechanisms of post-translational regulation of expression of miRs genes.

In case if miRs genes are located within the intergenic region, pri-miRs are transcribed with RNA-polymerase II [30, 31], at the same time, if they are localized in introns, then the production of pri-miR is also supplemented by the mechanism of RNA splicing $[10,11]$. In some cases miRs are transcribed by RNA-polymerase III. Thus, authors of [32] demonstrated that the cluster of miRs genes, located among Alu-repeats on human chromosome 19, is transcribed by RNA-polymerase III but not RNA-polymerase II.

It remains unknown whether it is a unique case or a rule for miRs genes, located in genome regions, transcribed by RNA-polymerase III. Authors in [33] determined the majority of the investigated miRs genes of nematode, human, and two plant species to possess the same type of promoter specific for protein-encoding genes (TATA). However, a significant number of 
genes are of indefinite type. The authors developed a new method of foreseeing the promoters, reminding cis-acting elements, for transcription initiation. The value and the secondary structure of transcribed pri-miRs may vary significantly [31]. Length-wise they may be from 100 to several thousand nucleotides long. There are cases of pri-miRs, specific for poly-A-sequences and cap structure, i.e. capable of performing functions of mRNA [34]. The specificity of secondary structure of pri-miRs is the presence of hair-loop structure - hairpins - regardless of their length [35]. In some cases, they may contain 1-2 hairpins [36] or several as in the case of cluster localization of pri-miR genes [9, 37, 38].

The next stage of miR biogenesis is the splitting of pri-miR in the nucleus by RNAase III, also called Drosha [35]. Scheme of miR biogenesis is presented in Fig.1. Drosha chips off the hairpin out of pri-miR miR precursor, pre-miR. Certain rules have to be abided regarding the structure of pre-miR hairpin as a part of pri-miR for successful chipping off by Drosha. Split takes place between several (1-5) non-paired bases, then hairpin stem, containing not less than 10 b.p., is split. Hairpin stem may include non-paired bases as well. The most successful splitting occurs at the presence of branchy non-paired chains at the hairpin base. Chipping off takes place at the base and captures 1-2 nucleotides of the hairpin stem. The length of pre-miR may usually vary ( $\approx 50-80$ nucleotides). Hairpins may include non-paired bases of both arms ( $5^{\prime}$ and $3^{\prime}$ ), forming symmetrical loop, and of one arm only asymmetrical loops (up to 10 b.p.). Yet exceptions may occur. The presence of pri-miR hairpins in plants is not considered to be the rule. pre-miR hairpins, if they are processed, vary significantly in length (from 60 up to 300 nucleotides) and in shape [39, 40]; e.g. pre-miR-169, 196 nucleotides long, contains one asymmetrical loop, 44 nucleotides long, in each of the stem arms [39]. In most of the cases, mature miRs are chipped off double-stranded extended pri-miR regions, which do not necessarily form hair-pin loop structure [40]. Later on we will discuss some possible reasons of such exceptions.

Drosha enzyme is known to function in the human body with RNA-binding protein, called Pasha or DGCR-8 [41] (Fig.1). In this tandem Pasha acts as
pri-miR binding protein, while Drosha provides nucleolytic activity of the complex. Pasha protein consists of 773 amino acid residues and contains N-terminal domain (1-275), responsible for nuclear localization, two domains in C-terminal region, responsible for pri-miR binding and one domain (692-750) is responsible for binding with Drosha [41]. Authors of [42] suggested the model of recognition of pri-miR by DGCR-8 protein on crystallographic structure of core region of 429-720. Crystallographic structure of C-terminal domain of Dicer, responsible for production of miRs, was studied by Takeshita et al. [43]. Drosha in mice is represented by a complex of two subunits, one of which is DEAD-containing helicase subunit which recognizes pri-miR [44].

The next stage of miR biogenesis is export of pre-miR hairpins, chipped off pri-miR, from the nucleus to cytoplasm [45-47] (Fig.1), carried out with the participation of protein translocation factor Exportin 5. In cytoplasm pre-miR interacts with Dicer endonuclease, which cuts double stranded intermediate product $\mathrm{miR} / \mathrm{miR}^{*}, 20-25$ nucleotides long, out of the hairpin. This product initiates the formation of effector RNA-induced complex, resulting in silencing of genes, i.e. RISC - RNA induced silencing complex, the main protein components of which are Dicer, helicase, RNA-binding protein, and argonaute-protein, responsible for the formation of RISC [5-7, 48-52]. In Drosophila Dicer-processing enzyme as a part of RISC-complex functions in tandem with RNA-binding protein Loqs, which results in the formation of intramolecular dimer [48]. Authors describe "functional anatomy" of Dcr-1/Loqs-complex and details of pre-miR splitting mechanism.

Helicase is known not only to untwist $\mathrm{miR} / \mathrm{miR}^{*}$-duplex but also to be a significant component of miR metabolism. Along with other components, helicase takes part in "loading" of RISC-complex [49].

Plants are specific for a different mechanism of splitting. They possess four Dicer-like enzymes [50]. In Arabidopsis, DCL-1 protein and two other proteins HYL-1 and SE form an intramolecular complex, which is included into $\mathrm{SmD} 3 / \mathrm{SmB}$-body, localized in the nucleus [51]. The authors put forward a supposition that DCL-1/HYL-1/SE-complex is involved into miR pro- 


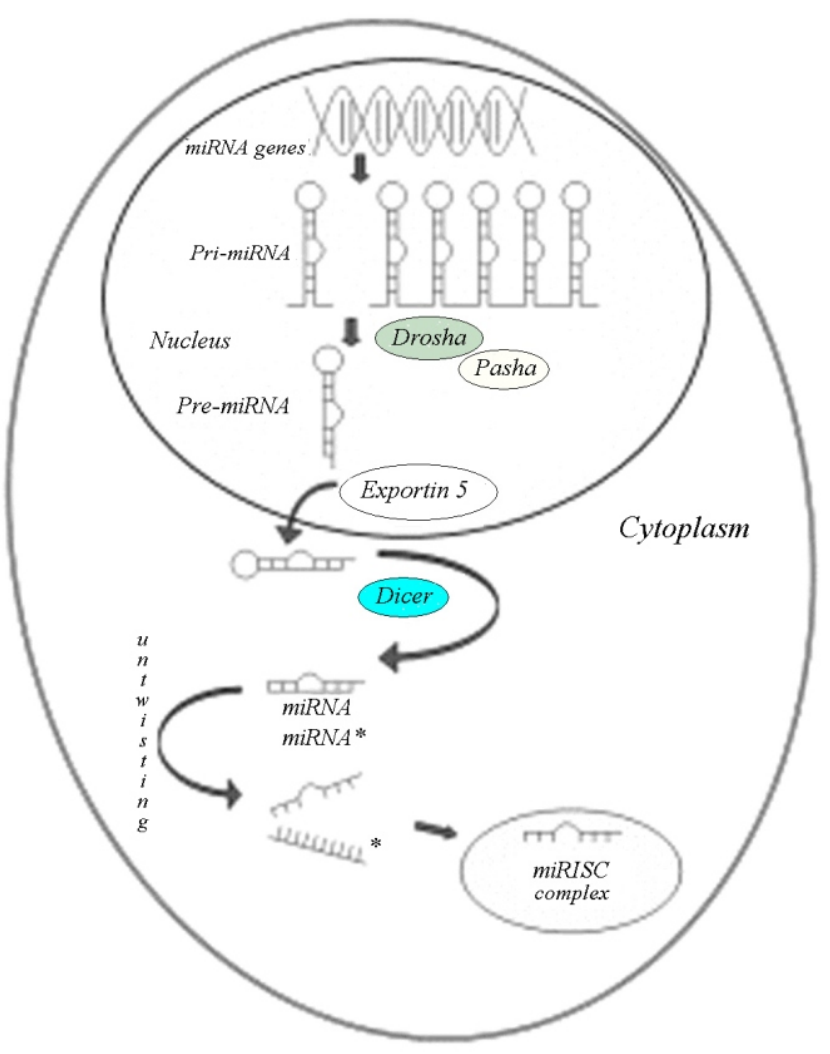

Fig. 1. Scheme of miR biogenesis. See text for details.

duction in the nuclear $\mathrm{SmD} 3 / \mathrm{SmB}$-bodies. These data are confirmed by results in [52]. Dicing (D)-bodies, as defined by the authors of [52], take part in "symphonic" processing of pri-miR-pre-miR-miR in nuclei of plant cells. The facts mentioned (the existence of four DCL-enzymes, nuclear localization of D-bodies) allow supposing that plants are specific for the absence of intermediate product of miR-metabolism - pre-miR - and the above mentioned abnormal hairpins are the discovered pri-miRs.

Helicase in RISC-complex or in D-bodies untwists $\mathrm{miR} / \mathrm{miR}^{*}$, passenger $\mathrm{miR}^{*}$ chain is eliminated, and RISC remains with complementary chain of 20-25 nucleotides long, i.e. mature miR. Mature miR may be processed from either $5^{\prime}$ - or $3^{\prime}$-arm of pre-miR, or from both arms. The latter fact is supposed to depend on thermodynamic stability of $5^{\prime}$ - or $3^{\prime}$-arms of pre-miR. The cells usually choose the least stable miR and destroy the other one. Nevertheless, Ro et al. [53] demonstrated that in some tissues both chains may be accumulated as paired miRs until they are not subjected to the selection in other tissues. Both miRs are capable of suppressing expression of their genes in such tissues. Mammalian miRs may be imported back to the nucleus in some cases.

Thus, authors of [54] revealed that specific miRs sometimes contain additional hexanucleotide element in 5'-terminal sequence, which determines their subcellular localization. The same authors demonstrated that having joined miR-296, the mentioned terminal motif controls its nuclear import. The accumulation of mature miR in the nucleus was also shown in [55], where the authors defined that rat miR-206 is associated with forming ribosomes, as well as with $28 \mathrm{~S}$ rRNAs of functioning ribosomes in cytoplasm. This is a short review of the mechanism of miR gene expression. We may also suppose that plant miRs, formed in the nucleus, are exported into cytoplasm.

Mechanism of miRs functioning. How does the mature miR function? The model of miR functioning is presented in Fig.2. Having remained in RISC-complex miR becomes a "guide" for miRISC-complex. It guides effector RNP-complex to the target, which is presented by mRNA and where mature miR finds its complementary region. Due to miR complementarity with RNA-target the complex is retained on mRNA, inhibiting the process of translation $[45,46]$. Long et al. [56] revealed the influence of secondary structure of mRNA-target on recognition of its miRs. They also supposed the existence of two-step reaction of hybridization of miR and mRNA. A $\rightarrow$ I-editing of miRs and their targets influences the repertoire of mRNA-targets for miRs and redistribution of targets [26-29]. The mechanism of inhibition is of two sides and is known to depend on the degree of miR complementarity to its target. If miR is complementary in its $5^{\prime}$ - and $3^{\prime}$-terminal sequences, 5-7 nucleotides long, and is not complementary in the center (5-7 nucleotides), forming a ledge, then the complex is placed on $3^{\prime}$-untranslated region ( $3^{\prime}$ UTR) of mRNA. In this case the process of translation is inhibited. The selection of targets is influenced by some specificities of 3' UTR [57-59]. It was shown that successful inhibition is achieved with $5^{\prime}$ miR end, while $3^{\prime}$-end variability is possible [60-62]. There may be several binding centers on 3' UTR. For instance, mRNA lin-14, encoding nuclear protein, necessary for transition of Caenorhabditis elegans larva 


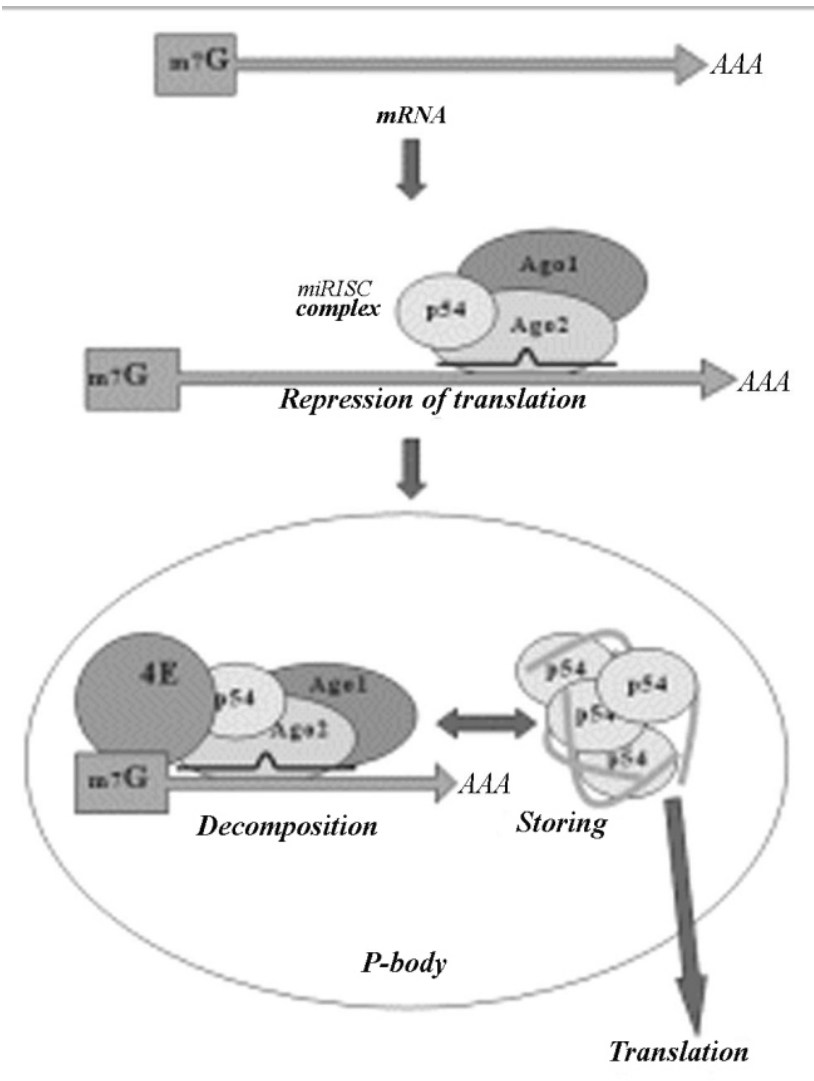

Fig. 2. The model of miR functioning. See text for details.

from age 1 to age 2, is known to contain seven binding centers with miR-lin4 [63]. The investigation of the mechanisms of inhibition has been commenced only recently [64] and it is far from giving clear results. There are several mechanisms, different in fine details of molecular interaction of RNA and protein components the participants of this complicated process [47, 65]. We will not take time to describe the details but will name only some stages of this process. Repression is known to require cap-structure and poly-A-sequence [66-69], and to occur after translation initiation [70]. Evident is the fact that binding of miRISC with mRNA-target takes place in polysomes. Thus, exponentially growing HeLa cells showed the majority of three miRs to be associated with actively translated mRNA, while human miR-let7a blocks protein synthesis on actively translating lin-41 mRNA polysomes, assisting in accumulation of growing polypeptides [71, 72]. Polysomes were precipitated in saccharose concentration gradient together with miR-let-7a and
Ago-protein. Supposedly, miRISC blocks protein synthesis, contributing to fast descent of ribosomes with growing polypeptide chains during translation elongation $[47,65]$. The destiny of the latter remains uncertain, yet some suppositions are presented in [47, 65]. Later on it has been determined that inhibited mRNA along with miRISC is associated with P-bodies (Fig.2) [45-47]. The authors of [73] showed that realization of mRNA out of polysomes is insufficient for the initiation of P-bodies assembly - released mRNA should take part in inhibition of metabolism, initiated by miR. The authors made the conclusion that P-bodies are not obligatory for functioning, but are the consequences of metabolism of silencing of genes with the participation of miR. P-bodies contain high concentrations of enzymes and factors, necessary for repression of translation or mRNA turnover. In this situation two variants are possible: i) miRISC interacts with decapping proteins and translation initiation factor $4 \mathrm{E}$, at the same time assisting in the inhibition and splitting of mRNA; ii) mRNA interacts with helicase protein $\mathrm{p} 54$, oligomerisation of complex p54-mRNA takes place and mRNA is preserved till better times. When necessary, this preserved mRNA may enter the translation cycle again [45, 74]. However, it remains unknown how the cell selects the way of realization. Besides, this scheme was determined for miR-let7, which is commonly known to split mRNA-targets, regardless of its incomplete complementarity (poly-A-sequence is chipped off) $[47,65,75]$.

This is the first supposable mechanism of inhibition of translation with miR, which is based on incomplete complementarity of miR and mRNA target, as a part of miRISC-effector complex, which engages miR "guiding" role, and effector protein p54 determines whether RNA should be split or preserved for further repeated translation [45].

The second mechanism of inhibition of miR translation in plants is the cutting of mRNA-target according to siRNA mechanism $[39,76,77]$. Similar mechanism was shown on one of miRs of BART2 of Epstein-Barr virus (EBV) [78]; it is performed in the cases when miR is completely complementary to its target. The splitting takes place via the centers of complementary regions. It is obvious that the selection of mechanism of inhibition depends on the complementarity of the central region of 
miR $\sim 7$ nucleotides long. Interestingly, in some cases the splitting, initiated by miR, results in the formation of siRNA out of mRNA splitting products $[40,76,77]$. Sometimes 5'-product of mRNA splitting does not synthesize siRNA. Some scientists believe that these unsplit 5'-products may be functionally necessary for plants. It is supposed that splitting of mRNA, resulting in siRNA formation, takes place outside of P-bodies.

The data of the type and place of miR splitting are rather controversial. There are some works that claim that splitting in some points takes place in endonuclease containing P-bodies [79]. However, it contradicts the data, obtained on miR-166 in Arabidopsis, the target for which is mRNA of PHV gene [77]. This work demonstrates that miR-166, completely complementary to its target, assists in splitting of mRNA, 656 nucleotides long, and the accumulation of 5'-terminal product of splitting, 500 nucleotides long. Dicer of RISC-complex, initiated by miR-166, acts as multiple-use enzyme, as one complex splits $\sim 30$ target molecules. This mechanism is unlikely to be the same if the complete splitting took place in P-bodies with endonuclease assistance. It is the most likely that the split in one point takes place in P-bodies according to the second type, with the accumulation of $5^{\prime}$-half of mRNA, as it has been shown for let-7 [45].

Up to this moment we reviewed the works, proving down-regulation of translation in case of miR binding to $3^{\prime}$-UTR mRNA (mammals, invertebrates) or to the encoding mRNA region (plants). However, miRs may also up-regulate mRNA, modulating the process of translation [80-82]. miRs can modulate binding centers for proteins, interacting with mRNA [80, 82]. It is supposed that binding of one or more miR to mRNA may result in conformational changes in mRNA, and consequently, to revealing or masking of additional regulatory elements on mRNA. This may occur in case of location of miR binding centres within 5'-non-coding region of mRNA-target. Up-regulation of expression of hepatitis virus type $\mathrm{C}$ was demonstrated during the interaction of miR-122, specific for host liver, with 5'-region of viral RNA [81]. Two miRs, interacting with 5'-region of their mRNA-targets, were discovered in plants (Arabidopsis) [83]. Evidently, modulation of translation process is performed when $\mathrm{miR}$ is bound to 3'-UTR mRNA and is accumulated in P-bodies for re- current translation, which was demonstrated for human let-7 miR [45].

On the basis of revealed mechanism of miR functioning a definite conclusion can be made that biological effect of miR depends on proteins, encoded in their mRNA-targets, as well as on the processes these proteins participate in. But before proceeding to that we need to mention the methods of discovery and identification of miR.

The strategy of discovery and investigation of miRs. As of today some strategies of discovering and investigating individual miR have already been developed, and some are still being elaborated, mainly including two basic approaches, namely biochemical and bioinformatical $[84,85]$. Biochemical approach uses total RNA, extracted from tissues, divided by either gel-filtration or electrophoresis in $15 \%$ polyacrylamide gel, containing sodium dodecyl sulfate and $7 \mathrm{M}$ urea, in order to isolate and to identify miR. The zone of low-molecular RNA (20-30 nucleotides) is modified and amplified with subsequent cloning and sequencing. The methods developed allow identifying miRs, different in one nucleotide, in 25 pmoles [86]. Thus, this is the way individual miRs are isolated and numbered. Besides, there is one work on isolating a specific 15S-complex of miR from RNP, containing 40 individual miRs, from HeLa cells [87]. Some methods developed are aimed at the identification of miRS expression profiles $[88,89]$, i.e. identification of time of appearance, synthesis, and elimination of miRs in the organs and tissues during carcinogenesis. Wang et al. [88] developed accurate and sensitive method of miRs profiling, which allows discriminating RNA in the cell degree- and sequence-wise and determining individual miRs in tissues, held by formalin and covered with paraffin. Work [90] can be an example of description of expression profiles of $23 \mathrm{miRs}$ in carcinogenesis of Drosophila at the embryonic stages, and larvae of three different age groups i.e. prepupal, pupal, and adult female. This work demonstrates that some miRs are synthesized constitutively during carcinogenesis (miR-1, miR-8), others at the stage of embryo only (miR-2, miR-3), and some - miR-34 - at the stage of larva, and are synthesized intensively in adult specimen, whereas miR-125 and let-7 - only at the stages of pupa. 
Let us have a look at the bioinformatical approach to investigation of miRs. Computer programs are being developed to predict the presence of hairpin-loop structures (pre-miR) and mature miRs as parts of these hairpins [91-94], as well as the presence of mRNA targets for miR [61, 85, 95-102]. The prediction of pre-miR and mature miR hairpins is based on one criterion: candidates for pre-miR should possess specific secondary structure of hairpin-loop shape, 60-100 nucleotides long, with several symmetrical or asymmetrical "bubbles" (several unpaired bases). Mfold computer program is the most wide spread [91]. There is also RNA fold-L-100 program [92], which is capable of differentiating real hairpins from pseudo ones among numerous pre-miR candidates with free folding energy $>23.00 \mathrm{ccal} / \mathrm{mol}$. To predict the presence of mature miR among pre-miR candidates there some computer programs like miRSeeker and miRScan, which select hairpins of 100 nucleotides long and total rating of $>10$. miRSeeker [93] and miRScan [94] are based on the criterion of conservatism of adult miRs, thus they select candidates after obligatory comparison of two related hairpins. This is main disadvantage of the mentioned computer programs and thus, the reason of their limited application, especially in the investigation on miRs, encoded in the genome of viruses. Biochemical approach confirmed that these computer programs do not identify many real miRs, they select the most probable ones, and then "real" hairpin-candidates, containing mature miRs. However, pri-, pre-, and mature miRs, predicted using this method, require additional confirmation of the fact that the precursors are the substrates for processing enzymes (Drosha, Dicer) [103]. Authors consider miRs, successful in passing this sort of selection, can be named the real miRs and unsuccessful ones - precursors. Bioinformatical investigation is usually confirmed by biochemical one (profiles of miRs expression, isolation of individual miRs and their sequencing) and visa versa.

Participation of miRs in cell process regulation. What are the results obtained for the last five years since the discovery of miRs in 2001 [104]?

First of all, all eukaryotic genomes investigated up to date contain miRs genes. The number of different miRs in different organisms is tens and hundreds in one organism. E.g. the number of miRs genes in human genome is supposed to exceed 1000 and may even reach 20000 , which is over $3 \%$ of encoding genome capacity, they may also control $30+\%$ of genes $[5-7,105,106]$. Even such small size-wise genomes as genomes of viruses contain up to several tens of miRs $[8,107,108]$ : EBV - 32 miRs [8]; rhesus lymphocryptovirus - 22 miRs; Kaposi sarcoma associated virus - 17 miRs; human cytomegalovirus - 14 miRs; mouse gamma herpes virus - 10 miRs [8]; human immunodeficiency virus 10 miRs [107]; Marek's disease virus -8 miRs [108]; simian SV40 - 8 miRs; herpes simplest virus $-1 \mathrm{miR}$ [8]. At the same time one miR may have tens and hundreds of different targets [5-7, 109]. Different transcription factors and many other protein-factors prevail among miR targets. Protein synthesis is regulated indirectly via the processes of transcription - down-regulation (suppression of synthesis) and up-regulation (restoration of synthesis). However, miRs are capable of not only suppressing translation (down-regulation) but also restoring it (up-regulation) [81, 82, 110].

Due to the effect on the process of transcription, miRs act as real regulators of numerous processes. Taking into account the fact that profiles of miRs expression are specific to various tissues, organs, and stages of carcinogenesis, it is clear why miRs are involved into control and regulation of processes of development, starting from embryogenesis [111-115] and up to adult organism [116-118], processes of differentiation [119-121] and cell growth [122-124], processes of tissue formation $[111,119,125]$ and of separate organs $[115,116,118,125-127]$. miRs control self-identification and differentiation of stem cells [113-115, 128], processes of proliferation and apoptosis [121, 129-134], they take part in the signaling systems of cells [135], in the regulation of endocrine $[119,136]$ and nervous $[5,119,137-141]$ systems, they function in hematopoiesis $[5,119,120$, 142-144], spermatogenesis [145], immunogenesis [146-151]. miRs possibly take place in alternative splicing [152] and together with siRNAs in epigenetic processes [153-156]. They are also involved into the metabolism of low-molecular compounds [157-161] (amino acids [158], lipids [159], glucose [160], phosphates [161]) and in the regulation of cell osmotic pressure [162]. miRs were shown to participate in the 
regulation of protein-protein interaction networking in humans [163].

miRs play the significant role in virus-cell interactions [8]. Generally these are miRs, encoded by large DNA-containing viruses, integrated into host genome, and retroviruses. Yet this is a whole different topic, which requires special attention.

miRs and diseases. Fundamental investigation of biogenesis and functioning of miRs attract special attention due to their involvement in various pathologies $[105,121,131,155,164-170]$, inflammatory processes $[171]$ and stresses $[167,169]$. Nowadays the methodology of studying the expression profiles of cell miRNAs in norm and pathologies is in progress $[104,106,121$, 131, 172-180]. There also occur some papers on the role of miRNA as a tool in the management of embryonic development and classification of human tumours $[121,174]$. On the basis of these works the supposition can be put forward that programs of development in all investigated organisms represent specific examples of miRNA expression profiles and disorders in these profiles correlate with different pathologies, in particular, virus infections [181] and carcinogenesis [106, 132-134, 173-179, 182-192]. Currently it has been shown that neoplasias are characterized by specifically changed profile of miRNA expression [121, 173-179, 189, 190, 193-198]. Not only changes in expression profiles but also the occurrence of specific miRs have been detected in various tumours [190, 193, 199-203]. Interestingly, both oncogenes and tumour suppressors may be considered as miRs [131, 176, 177, 185, 199-212].

$R N A i$-therapy. Totally new strategy of marking, diagnostics, prevention, and treatment of diseases is being developed due to the study of new miRs and their expression profiles $[106,121,169,175-180,184-187$, 203-205, 213-218] which involves the application of genetically and chemically modified miRs (antogomirs) along with siRNAs [191, 219-224]. The main task for the new generation of medical preparations for different types of pathologies is the determination of optimal modifications of chemically synthesized sense and antisense oligonucleotides. Delivery of oligonucleotides, vector selection, chemical modifications for protection from nucleases, elimination of side effects (interferon stimulation) - this is the list of the most important problems, waiting for their solution on the way to the introduction of fundamental knowledge on miRs into medical practice. In vivo toxicity of short hairpin RNA, conditioned by the saturation of metabolism of endogenic miRs, may hinder the implementation [225-226]. Researchers inquire whether these data would limit therapeutic application of short hairpin RNA.

John et al. try to answer this question [227]. These authors revealed that the silencing of target genes does not result in significant changes in levels of miR-122, mir-16, and let-7a, expressed in cells of rats and hamsters, via the application of synthetic siRNA, aimed at two hepatocyte-specific genes (apoliprotein B and factor VII). Scientists concluded that the application of synthetic miRs should not result in the disorders in the organism and thus, antogomirs may be considered "safe and effective silencing tool of gene transcripts". Stating on the abovementioned we may suppose that synthetic minor RNA can be applied as medical preparations. The key role in diagnostics and drug discovery within the new paradigm of development of personalized medicine, based on RNA-interference with miRs and siRNAs, belongs to miRs [228]. Although not even one single commercial medical preparation has been developed and only some are being clinically tested, future market of RNA-interference-based drugs is estimated to be $3.5 \cdot 10^{9}$ USD in 2010 and up to $10 \cdot 10^{10}$ USD in 2015 [228].

\section{Т. В. Ширина, М. Т. Бобровская, Э. А. Козлов}

МикроРНК: от фундаментальных исследований до их приложения

МикроРНК - малье, некодирующие белок РНК длиной 20-30 нуклеотидов. В клетках эукариотов микроРНК выполняют роль биорегуляторов экспрессии генов через механизм ингибирования или модуляции процесса трансляции. Цель обзора - проанализировать механизмы биогенеза $и$ функиионирования микроРНК, стратегию их открытия, предоставить краткий перечень биологических прочессов, в регуляции которых принимают участие микроРНК, а также ознакомить с новейтими публикациями, посвященными причастности микроРНК к различным патологиям (особенно канцерогенезу) и использованию их для маркирования, диагностики, профилактики и терапии раковых болезней человека.

Ключевые слова: микроРНК, биогенез, функиия, профили экспрессии, биоинформатическое предсказание, биорегуляиия, канцерогенез, терапия. 


\section{REFERENCES}

1. Pasquinelli A. E. Demistifying small RNA pathways // Develop. Cell.-2006.-10, N 4.-P. 419-424.

2. Plasterk R. H. A. RNA silencing: the genomes immune system // Science.-2002.-296.-P. 1263-1264.

3. Zamore R. D. Ancient pathways programmed by small RNAs // Science.-2002.-296.-P. 1265-1269.

4. Matzke M. A., Brichler J. A. RNA-mediated pathways in nucleuse // Nat. Rev.-2005.-6, N 1.-P. 24-35.

5. Zhao Y., Srivastava D. A developmental view of microRNA function // Trends Biochem. Sci.-2007.-32, N 4.-P. 189197.

6. Zhang B., Wang $Q$., Pan $X$. MicroRNAs and their regulatory roles in animals and plants // J. Cell Physiol.-2007.-210, N 2.-P. 279-289.

7. Wang Y., Stricker H. M., Gou D., Liu L. MicroRNA: past and present // Front Biosci.-2007.-12.-P. 2316-2329.

8. Scaria V., Hariharan M., Maiti S., Pillai B., Brahmachari S. $K$. Host-virus interaction: a role for micro RNAs // Retrovirology.-2006.-3.-P. 68-76.

9. Yu J., Wang F., Yang G. H., Wang F. L,, Ma Y. N., Du L.W., Zhang $J$. $W$. Human microRNA cluster: genomic organization and expression profile in leukemia cell lines // Biochem. and Biophys. Res. Communs.-2006.-349, N 1.P. 59-68.

10. Lis $C$., Tang P., Lin W. C. Intronic microRNA: discovery and biological implications // DNA Cell Biol.-2007.-26, N 2.P. 195-207.

11. Kim Y.-K., Kim V. N. Processing of intronic microRNA // EMBO J.-2007.-26.-P. 775-783.

12. Piriyapongsa J., Marino-Ramirez L., Jordan J. K. Origin and evolution of human microRNAs from transposable elements // Genetics.-2007.-176, N 2.-P. 1323-1327.

13. Kueiver J., Van den Berg A., de Long D., Blokzijl T., Harms G., Bauvman E., Jacobs S., Poppewa S., Kroesen B. J. Regulation of pri-microRNA BIC translation and processing in Burkitt lymphoma // Oncogene.-2007.-26, N 26.-P. 37693776.

14. Lee J., Li Z., Brower-Sinning R., John B. Regulatory circuit of human microRNA biogenesis // PLoS Comput. Biol.-2007.- 3, N 4.-e67.

15. Fukao T., Fukada Y., Kiga K., SharifJ., Hino K., Enomoto Y., Kawamura A., Nakamura K., Takeuchi T., Tanabe M. An evolutionarily conserved mechanism for microRNA-223 expression revealed by microRNA gene profiling // Cell.-2007.-129, N 3.-P. 617-631.

16. Shalgi R., Lieber D., Oren M., Dilpel Y. Global and local architecture of the mammalian microRNA-transcription factor regulatory network // PLos Comput. Biol.-2007.- 3, N 7.-e131.

17. Tsang J., Zhu S., van Oudenaarden A. MicroRNA mediated feedback and feedforward loops are recurrent network motifs // Mol. Cell.-2007.-26, N 5.-P. 753-767.

18. Xie L. R., Yang H. T., Liu W. C., Hwang M. J. The role of microRNA in the delayed negative feedback regulation of gene expression // Biochem. and Biophys. Res. Communs.-2007.-358, N 3. P. 722-726.

19. Chuang J. C., Jones P. A. Epigenetics and microRNAs // Pediatr. Res.-2007.-61, N 5, Pt 2.-P. 24R-29R.

20. Weber B., Streseman C., Brueckner B., Lyko F. Methylation of human microRNAs genes in normal and neoplastic cells // Cell Cycle.-2007.-6, N 9.-P. 1001-1005.
21. Han L., Witmer P. D., Casey E., Valle D., Sukumar S. DNA methylation microRNA expression // Cancer Biol. Ther.-2007.-6, N 8.-[Epub ].

22. Duan R., Pak C., Jin P. Single nucleotide polymorphism associated with mature miR-125a alters the processing of pri-miRNA // Hum. Mol. Genet.-2007.-16, N 9.-P. 11241131.

23. Sethupathy P., Borel C., Gagnebin M., Grant G. R., Deutsch S., Elton T. S., Hatzigeorgiou A. G., Antonarakis S. E. Human microRNA-155 on chromosome-21 differentially interects with its polymorphic target in the AGTRL 3' untranslated region: mechanism for fuctional single-nucleotide polymorphisms related to phenotypes // Am. J. Hum. Genet.2007-81, N 12.-P. 405-413.

24. Barnes M. R., Deharo S., Grocock R. Y., Brown J. R., Sanseau $P$. The microRNA target paradigm: a fundamental and polymorphic control layer of cellular expression // Exp. Opin. Biol. Ther.-2007.-7, N 9.-P. 1387-1399.

25. Amariglio N., Rechavi G. A- to -I RNA editing: a new regulatory mechanism of global gene expression // Biol. Cells Mol. Dis.-2007.-39, N 2.-P. 151-155.

26. Das A. K., Carmichall G. G. ADAR edition wobbles the microRNA world // ACS Chem. Biol.-2007.-2, N 4.P. 217-230.

27. Habig J. W., Dale T., Bass B. L. MiRNA-editing - we should have inosine this coming // Mol. Cell.-2007.-25, N 6.P. 792-793.

28. Kawahara Y., Zinshteynt B., Sethupathy P., Likasa H., Hatzigeorgiou A. G., Nishikura K. Redirection of silencing targets by adenosine-to-inosine editing of miRNAs // Science.-2007.-3515, N 5815.-P. 1137-1140.

29. Liang H., Landweber L. F. Hypothesis: RNA editing of microRNA target sites in humans? // RNA.-2007.-13, N 4.-P. 463-467.

30. Lee J., Kim M., Han J., Yeom K.-H., Lee S., BackS. H., Kim V. $N$. MicroRNA genes are transcribed by RNA polymerase II // EMBO J.-2004.-23.-P. 4051-4060.

31. Bartel D. P. MicroRNAs: genomics biogenesis, mechanism and function // Cell.-2004.-116.-P. 281-297.

32. Borchert G. M., Lanier W., Davidson B. L. RNA polymerase III transcribes human microRNAs // Nat. Struct. Mol. Biol.-2006.-13, N 12.-P. 1097-1101.

33. Zhou X., Ruan J., Wang G., Zhang W. Characterization and identification of microRNA core promoters in four model species // PLoS Comput. Biol.-2007.-3, N 3.-e37.

34. Cai X., Hagedorn C. H., Cullen B. R. Human microRNAs are processed from capped, polyadenylated transcripts that can also function as mRNA // RNA.-2004.-10.-P. 1957-1966.

35. Zeng J., Cullen B. R. Efficient processing of primary microRNA hairpins by Drosha reuires flanking nonstructured RNA sequence // J. Biol. Chem.-2005.-280, N 30.-P. 27595-27603.

36. Bashirullah A., Pasquinelli A. E., Kiger A. A., Perriman N., Ruvkun G., Tummel C. S. Coordinate regulation of small temporal RNAs at the onset of Drosophila metamorphosis // Develop. Biol.-2003.-259.-P. 1-8.

37. Lau N. C., Lim L. P., Weinstein E. G., Bartel D. P. An abundant class of tiny RNAs with probably regulatory roles an Caenorabditis elegans // Science.-2001.-294, N 5543.P. 858-862.

38. Mineno J., Okamoto S., Ando T., Sato M., Chong H., Izu H., Takayama M., Asada $K$. The expression profile of microRNAs in mouse embryos // Nucl. Acids Res.-2006.-34, N 6.-P. 1763-1771. 
39. Reinhart B. J., Weinstein E. G., Rhoades M. W., Bartel B. MicroRNAs in plants // Genes Develop.-2002.-16, N 13.P. 1616-1626.

40. Qui C. X., Xie F. L., Zhu Y. Y., Guo K., Huang S. O., Nie L., Yang Z. M. Computational identification of microRNAs and their targets in Gossypium hirsutum expressed sequence tags // Gene.-2007.-395, N 1-2.-P. 49-61.

41. Jeom K. H., Lee J., Han J., Suh M. R., Kim V. N. Characterization of DGCR8/Pasha, the essential cofactor for Drosha in primary miRNA processing // Nucl. Acids Res.-2006.-34, N 34.-P. 4622-4629.

42. Sohn S. Y., Bawe W. J., Kim J. J., Yeom K. H., Kim V. N., Cho $Y$. Cristal structure of human DGCR8 core // Nat. Struct. Mol. Biol.-2007.-14, N 9.-P. 847-853.

43. Takeshita D., Zenno S., Lee W. C., Nagata K., Saigo K., Tanokura M. Homodimeric structure and double-stranded RNA cleavage activity of the C-terminal RNAse III domain of human Dicer // J. Mol. Biol.-2007, Sep. 8 [Epub.].

44. Fukuda T., Yamagata K., Fujiyama S., Matsumoto T., Koshida I., Yoshimura K., Mihara M., Naitou E., Endoh H., Nacamura T., Akimoto C., Yamomoto Y., Katagiri T., Foulds C., Takezawa S., Kitagawa H., Takeyama K., O'Malley B. W., Kato $S$. DAED-box RNA helicase subunits of the Drosha complex are required for processing of rRNA and a subset of microRNA // Nat. Cell Biol.-2007.-9, N 5.-P. 604-611.

45. Chu Y., Rana T. M. Traslation repression in human cells by microRNA-induced gene silencing requires $\mathrm{RCK} / \mathrm{p} 54 / /$ PLoS Biol.-2006.-4, N 7.-e210.

46. Jackson J., Standart N. How do microRNA regulate gene expression? // Sci. STKE.-2007.-N 367.-P. re 1.

47. Pillai R. S., Bhattacharyya S. N., Filipowicz W. Repression of protein synthesis by miRNAs: how many mechanisms? // Trend Cell Biol.-2007.-17, N 3.-P. 118-126.

48. Ye X., Paroo Z., Liu O. Functional anatomy of the Drosophila microRNA-generating enzyme // J. Biol. Chem.-2007.-282, N 39.-P. 28373-28378.

49. Salzman D. W., Shubert-Coleman J., Furneaux H. P68RNA helicase unwinds the human let-7 microRNA precursor duplex and is required for let-7 directed silencing of gene expression // J. Biol. Chem.-2007.-282, N 40.P. 32773-32779.

50. Blevins T., Rajeswaran R., Shivaprasad P. V., Beknazariants D., Si-Ammour A., Park H.-S., Vazquer F., Robertson D., Meins F. Jr., Hohn T., Pooggin M. M. Four plant Dicer mediate viral small RNA biogenesis and DNA virus induced silencing // Nucl. Acids Res.-2006.-34, N 21.-P. 62336246.

51. Fujioka Y., Utsumi M., Ohba Y., Watanaba Y. Location of a possible miRNA processing site in $\mathrm{SmD} 3 / \mathrm{SmB}$ nuclear bodies in Arabidopsis // Plant. Cell Physiol.-2007.-48, N 9.-P. 1243-1253.

52. Fang Y., Spector D. L. Identification of nuclear Dicing bodies containing proteins for microRNA biogenesis in living Arabidopsis plants // Curr. Biol.-2007.-17, N 9.-P. 818-823.

53. Ro S., Park C., Young D., Sanders K. M., Yan W. Tissue-dependent paired expression of miRNAs // Nucl. Acids Res.-2007.-35, N 17.-P. 5944-5953.

54.Hwang H. W., Wentzel E. A., Mendell J. T. A hexanucleotide element directs microRNA nuclear import // Science.-2007.-315, N 5808.-P. 97-100.

55.Politz J. C., Zhang F., Pederson T. MicroRNA-206 colocalizes with ribosome-rich regions in both the nucleous and cytoplasm of rat myogenic cells // Proc. Nat. Acad. Sci. USA.-2006.-103, N 50.-P. 18597-18620.
56. Long D., Lee R., Williams P., Chan C. Y., Ambros V., Ding J. Potent effect of target structure on microRNA function // Nat. Struct. Mol. Biol.-2007.-14, N 4.-P. 287-294.

57. Majoros W. H., Ohler U. Spatial preferences of microRNA targets in 3' untranslated regions // BMC Genom.-2007.-8, N 1.-P. 152-160.

58. Hon I. S., Zhang Z. The role of binding site arrangement and combinatorial targeting in microRNA expression of gene expression // Genome Biol.-2007.-8, N 8.-P. R166.

59. Grimson A., Farh K. K., Johnston W. K., Garrett-Engele P., Lim L. A., Bartel D. P. MicroRNA targeting specificity in mammalians: determinants beyond seed pairing // Mol. Cell.-2007.-27, N 1.-P. 91-105.

60. Wang B., Love T. M., Call M. E., Doench J. G., Novina C. D. Recapitulation of short RNA-directed translational gene silencing in vitro // Mol. Cell.-2006.-22, N 4.-P. 553-560.

61. Rajwsky N. MicroRNA target predictions in animals // Nat. Genet.-2006.-38.-S8-S13.

62. Brenhecke J., Stark A., Russel R. B., Cohen S. M. Principles of microRNA-target recognition // PLoS Biol.-2005.-3.e85.

63. Lin H. L., Hannon G. J. MicroRNAs: small RNAs with a big role in gene regulation // Nat. Genet.-2004.-5.-P. 522-531.

64. Maister $G$. miRNAs get an early start on translational silencing // Cell.-2007.-131, N 1.-P. 25-28.

65. Nilsen T. $W$. Mechanisms of microRNA-mediated gene regulation in animal cells // Trends Genet.-2007.-23, N 5.P. 243-249.

66. Thermann R., Hentze M. W. Drosophila miR-2 induces pseudo-polysomes and inhibits translation initiation // Nature.-2007.-447, N 7146.-P. 875-878.

67. Kiriakidou M., Tan G. S., Lamprinaki S., De Planell-Saquer M., Nelson P. T., Mourelatos Z. An mRNA $\mathrm{m} 7 \mathrm{G}$ cap binding-like motif within human Ago2 repression translation // Cell.-2007.-129, N 6.-P. 1141-1151.

68. Mathonnet G., Fabian M. R., Svitkin Y. V., Parsyan A., Huck L., Murata T., Biffo S., Merrick W. C., Darzynkiewicz E., PiMai R. S., Filipowicz W., Duchaine T. F., Sonenberg N. MicroRNA inhibition of translation initiation in vitro by targeting the cap-binding complex eIR4F // Science.2007.-317, N 5845.-P. 1764-1767.

69. Standart N., Jackson R. J. MicroRNA repress translation of $\mathrm{m} 7 \mathrm{ppp}$-capped target mRNAs in vitro by inhibition initiation and promoting deadenylation // Genes Develop.-2007.-21, N 16.-P. 1975-1982.

70. Peterson C. P., Bordeleau M. E., Pelletier S., Sharp P. A. Short RNAs repress translation after initiation in mammalian cells // Mol. Cell.-2006.-21.-P. 533-542.

71. Maroney P. A., Yu Y., Fisher J., Nilsen T. W. Evidence that microRNAs are associated with translating messenger RNAs in human cells // Nat. Struct. Mol. Biol.-2006.-13, N 12.P. 1102-1107.

72. Nottrott S., Simard M. J., Richter J. D.Human let-7a miRNA blocks protein production on actively translating polyribosomes // Nat. Struct. Mol. Biol.-2006.-13, N12.P. 1108-1114.

73. Eulalio A., Behm-Ansmant I., Schweizer D., Izaurralde E. P-body formations a consequence, but the cause of RNA-mediated gene silencing // Mol. Cell Biol.-2007.-27, N 11.-P. 3970-3981.

74. Chan S. P., Slack F. J. MicroRNA-mediated silencing inside P-bodies // RNA Biol.-2006.-3, N 3.-P. 97-100.

75. Bagga S., Bracht J., Hunter S., Massirer K., Holtz J., Eachus R., Pasquinelly A. E. Regulation by let-7and lin-4 miRNAs 
results in target mRNA degradation // Cell.-2005.-122.P. 553-563.

76. Tang G., Reinhart B. J., Bartel D. P., Zamore P. D. A biochemical framework for DNA silencing in plant // Genes Develop.-2003.-17.-P. 49-63.

77. Axtell M. J., Jan C., Rajagopalan R., Bartel D. P. A two-hit trigger for siRNA biogenesis in plants // Cell.-2006.-127, N 3.-P. 565-577.

78. Cai X., Schafer A., Lu S., Bilello J. P., Desrosiers R. C., Edwards R., Raab-Traub N., Cullen B. R. Epstein-Barr virus microRNA a reevolutionarily conserved and differentially expressed // PLoS Pathol.-2006.-2, N 3.-e23.

79. Kim H. K., Lee J. S., Sivaprasad U., Malhotra A., Dutta A. Muscle-specific microRNA miR-206 promotes muscle differentiation // J. Cell Biol.-2006.-174, N 5.-P. 677-687.

80. George A, D., Tenenbaum S. A. MicroRNA modulation of RNA-binding protein regulatory elements // RNA Biol.2006.-3, N 2.-P. 57-59.

81. Jopling C. L., Yi M., Lancaster A. M., Lemon S. M., Sarnov P. Modulation of hepatitis $\mathrm{C}$ virus RNA abundance by a liver-specific microRNA // Science.-2005.-309.- P. 15771581 .

82. Leung A. K., Sharp P. A. MicroRNA: a safeguard against turmoil? // Cell.-2007.-130, N 9.-P. 581-585.

83. Sunkar R., Zhu J. K. Novel and stress-regulated microRNA and other small RNAs from Arabidopsis // Plant Cell.-2004.-16, N 8.-P. 2001-2019.

84. Berezikov E., Cuppen E., Plasterek R. H. A. Approaches to microRNA discovery // Nat. Genet.-2006.-38.-S2-S7.

85. Zang R., Pan X., Wang Q., Cobb G. P., Andersen T. A. Computational identification of microRNAs and their targets // Comput. Biol. Chem.-2006.-30, N 6.-P. 395-407.

86. Chen C., Ridzon D. A., Broomer A. J., Zhou Z., Lee D. H., Nguyen J. T., Barbisin M., Xu N. Z., Mahuvakar V. R., Andersen M. R., Zao K. Q., Livak K. J., Guegler K. J. Real-time quantification of microRNAs by steam-loop RT-PCR // Nucl. Acids Res.-2005.-23, N 20.-e179.

87. Mourelatos Z., Dostie J., Paushkin S., Sharma A., Charroux B., Abel L., Rappsilber J., Mann M., Dreyfuss G. MiRNAs: a novel class of ribonucleoproteins containing numerous microRNAs // Genes Develop.-2002.-16.-P. 720-728.

88. Wang H., Ach R. A., Curry B. Direct and sensitive miRNA profiling from low-input total RNA // RNA.-2007.-13.P. 151-159.

89. Einat $P$. Methodologies for high-through put expression profiling of microRNAs // Meth. Mol. Biol.-2006.-342.P. 139-157.

90. Sempere L. F., Sokol N. S., Dubrovsky E. B., Berger E. M., Ambros $V$. Temporal regulation of microRNA expression in Drosophila melanogaster mediated by normal signals and broad-complex gene activity // Develop. Biol.-2003.-259.P. 9-18.

91. Zuker M. Mfold web server for nucleic acid folding and hybridization prediction // Nucl. Acids Res.-2003.-31.P. 3406-3415.

92. Xue C., Li F., He T., Liu G. P., Li Y., Zhang X. Classificationof real and pseudomicroRNA precursors using local structure-sequence features and support vector mashine // Bioinformatics.-2005.- 6.-P. 310-316.

93. Lai E. C., Tomancak P., Williams R. W., Rubin G. M. Computational identification of Drosophila microRNA genes // Genom. Biol.-2003.-4, N 7.-R42.

94. Lim L. P., Lau N. C., Weinstein E. G., Abdelhakim A., Yekta S., Rhoades M. W., Burge C. B., Bartel D. P. The microRNAs of Caenorhabditis elegans // Genes Develop.-2003.-17.P. 991-1008.

95. $\mathrm{Ng} \mathrm{K}$. L., Mishra S. K. De novo SVM classification of precursor microRNA from genomic pseudo hairpins using global and intrinsic folding measures // Bioinformatics.2007.-23, N 11.-P. 1321-1330.

96. Chaudhuri K., Chatterjee R. MicroRNA detection and target prediction: integration of computational and experimental approaches // DNA Cell Biol.-2007.-26, N 5.-P. 321-337.

97. Watanabe Y., Tomita M., Kanai A. Computational methods for microRNAs target prediction // Meth. Enzymol.2007.-427.-P. 65-86

98. Huang J. C., Morris O. D., Frey B. J. Bayesian inference of microRNA targets from sequence and expression data // J. Comput. Biol.-2007.-14, N 5.-P. 550-563.

99. Doran J., Strauss W. M. Bioinformatic trends for the determination of miRNA-target interactions in mammals // DNA Cell Biol.-2007.-26, N 5.-P. 353-360.

100. Lindow M., Gorodkin J. Principles and limitations of computational microRNA gene and target finding // DNA Cell Biol.-2007.-26, N 5.-P. 339-351.

101. Yousef M., Jung S., Kossenkov A. V., Showe L. C., Showe M. $K$. Naive Bayes for microRNA target predictions machine learning for microRNA targets // Bioinformatic.-2007.-23, N 22.-P. 2987-2992.

102. Maziere P., Enright A. J. Prediction of microRNA targets // Drag. Discov. Today.-2007.-12, N 11-12.-P. 452-458.

103. Helvik S. A., Snove O., Saetrom P. Reliable prediction of Drosha processing sites improves microRNA gene prediction // Bioinformatics.-2007.-23, N 2.-P. 142-149.

104. Lagos-Quintane M., Rauhut R., Zenderkel W., Tushl T. Identification of novel genes coding for small expressed RNAs // Science.-2001.-294, N 5543.-P. 853-858.

105. Perera R. J., Ray A. MicroRNAs in the search for understanding human diseases // BioDrugs.-2007.-21, N 2.-P. 97-104.

106. Ahmed F. E. Role of miRNA in carcinogenesis and biomarker selection: a methodological view // Exp. Rev. Mol. Diagn.2007.-7, N 5.-P. 569-603.

107. Bennasser Y., Le S. Y., Yeung M. Z., Yeung K. T. HIV-1 encoded candidate microRNAs and their cellular targets // Retrovirology.-2004.-22, N 3.-P. 192-200.

108. Burnside J., Bernberg E., Anderson A., Lu C., Meyer S., Green P. J., Jain N., Isaacs G., Morgan R. W. Marek's Disease virus encodes microRNAs that map to nuq and the latency-associated transcript // J. Virol.-2006.-80, N 17.P. 8778-8786.

109. Lewis B. P., Burge C. B., Bartel D. P. Conserved seed pairing of ten flanked by adenosines indicates that thousands of human genes are microRNAs targets // Cell.-2005.-120.P. 15-20.

110. Bhattacharyya S. N., Habermacher R., Martine U., Closs E. $J$, Filipowicz $W$. Relief of RNA-mediated translational repression in human cells subjected to stress // Cell.-2006.-125.-P. 1111-1124.

111. Yu Z., Jian Z., Shen S. H., Purisima E., Wang E. Global analysis of microRNA target gene expression reveals, that microRNA target are lower expressed in mature mouse and Drosophila tissues than in the embryos // Nucl. Acids Res.-2007.-35, N 1.-P. 152-164.

112. Darnell D. K., Kaur S., Stanislaw S., Konieczka J. K., Yatskievych T. A., Antin P. B. MicroRNA expression during chick embryo development // Develop. Dyn.-2006.-235, N 11.-P. 3156-3165. 
113. Chen C., Ridzon D., Lee C. T., Blake J., Sun Y., Strauss W. M. Defining embryonic stem cell identity using differentian-relation microRNAs and their potential targets // Mamm. Genome.-2007.-18, N 5.-P. 316-327.

114. Puceat M., Ballis A. Embryonic stem cells: from bench to bedside // Clin. Pharmacol. Ther.-2007.-82, N 3.-P. 337339.

115. Wang Y., Medvid R., Melton C., Jeanisch R., Blelloch R. DGCR8 is essential for microRNA biogenesis and silencing of embryonic stem cell self- renewal // Nat. Genet.-2007.-39, N 3.-P. 380-385.

116. Sempere L. F., Cole C. N., McPeek M. A., Peterson K. J. The phylogenetic distribution of metazoan microRNAs: insights into evolutionary complexity and constraint // J. Exp. Zool. B Mol. Develop. Evol.-2006.-306, N 6.-P. 575-588.

117. Zhang B., Pan X., Anderson T. A. Identification of 188 conserved maize microRNAs and their targets // FEBS Lett.-2006.-580, N 15.-P. 3753-3762.

118. Xia X. G., Zhou H., Samper E., Melov S., Xu Z. Pol II expressed shRNA Sod 2 gene expression and causes phenotypes of the gene knockdown in mice // PLoS Genet.-2006.-2, N 1.-e10.

119. Song L., Tuan R. S. MicroRNA and cell differentiation in mammalian development // Birth Defects Res. C. Embryo Today.-2006.-78, N 2.-P. 140-149.

120. Min $H$., Chen C. Z. Methods for emalyzing microRNA expression and function during hematopoietic lineage differentiation // Meth. Mol. Biol.-2006.-342.-P. 209-227.

121. Chen Y., Stallings R. L. Differential patterns of microRNA expression in neuroblastoma are correlated with prognosis, differentiation, and apoptosis // Cancer Res.-2007.-67, N 3.-P. 976-983.

122. Raftopoulou M. MicroRNA signals cell fate // Nat. Cell. Biol.-2006.-8, N 2.-P. 112.

123. Yang J. H., Han S. J., Yoon E. K., Lee W. S. Evidence of auxin signal pathway, microRNA 167- ARF8-GH3, and its response to exogenous auxin in cultural rice cells // Nucl. Acids Res.-2006.-34, N 6.-P. 1892-1899.

124. Carleton M., Cleary M. A., Linsley P. S. MicroRNA and cell cycle regulation // Cell Cycle.-2007.-6, N 17.-P. 21272132.

125. Ryan D. G., Oliveira-Fernandes M., Lavker R. M. MicroRNA of the mammalian eye display distinct and overlapping tissue specificity // Mol. Vis. 2006.-12.P. 1175-1184.

126. Karali M., Peluso I., Marigo V., Barifi S. Identification and characterization of microRNAs expressed in the mouse eye // Invest. Ophthalmol. Vis. Sci.-2007.-48, N 2.- P. 509-512.

127. Bland C. S., Cooper T. A. Micromanaging alternative splicing during muscle differentiation // Genes Develop.-2007.-21, N 1.-P. 71-84.

128. Oakley E. J., Van Zant G. Unraveling the complex regulation of stem cells: implications for aging and cancer // Leukemia.-2007.-21, N 4.-P. 612-621.

129. Chang T. C., Wentzel E. A., Kent O. A., Ramachandran K., Mullendore M., Lee K. H., Feldmann G., Ymakuchi M., Ferlito M., Lowenstein C. J., Arking D. E., Beer M. A., Maitra A., Mendell J. T. Transactivation of miR-34a by P53 broadly influences gene expression and promotes apoptosis // Mol. Cell.-2007.-26, N 5.-P. 745-752.

130. Raver-Shapira N., Marciano E., Meih E., Sepetor Y., Rosenfeld N., Moskovits N., Bentwich Z., Oren M. Transcriptional activation of miR-34 a contributes to p53-mediated apoptosis // Mol. Cell.-2007.-26, N 5.-P. 731743.

131. Zhang B., Pan X., Cobb G. P., Anderson T. A. MicroRNAs as oncogene and tumor suppressor // Develop. Biol.-2007.-302, N 8.-P. 1-12.

132. Coller H. A., Forman J. J., Legesse-Miller A. «Myc'ed messages»: myc induces transcription of E2F1 while inhibiting its translation via a microRNA polycystron // PLoS Genet.-2007.-3, N 8.-e146.

133. Molt J. L., Kabayashi S., Bronk J. F., Gores G. J. mir-29 regulates Mcl-1 protein expression and apoptosis // Oncogene.-2007.-26, N 42.-P. 6133-6140.

134. le Sage C., Nagel R., Egan D. A., Schrier M., Mesman E., Mangiola A., Anile C., Maira G., Mercatelli N., Ciafre S. A., Farace M. G., Agami R. Regulation of the p27 (Kip 1) tumor suppressor by mir-221 and mir-222 promotes cancer cell proliferation // EMBO J.-2007.-26, N 15.-P. 3699-3708.

135. Cui Q., Yu L., Purisima E. O., Wang E. Principles of microRNA regulation of a human cellular signaling network // Mol. Syst. Biol.-2006.-2.-P. 46-52.

136. Valdstrup $S$. The adaptation of TSH secretion to autonomy in non-toxic goiter may be based on active regulation of set-point and sensivity of central TSH-receptor, perhaps by the microRNA (MIR) gene // Med. Hypothesis.-2006.-67, N 3.-P. 588-591.

137. Mark F., Mehler M. F., MattickJ. S. Non-coding RNAs in the nervous system // J. Physiol.-2006.-575, N 2.-P. 333-341.

138. $W u J$., Xie X. Comparative sequence analysis an intricate network among REST, CREB and miRNA in mediating neuronal gene expression // Genome Biol.-2006.-7, N 9.-R85.

139. Kosik K. S. The neuronal microRNA system // Nat. Rev. Neurosci.-2006.-122.-P. 911-920.

140. Makeyv E. V., Zhang J., Carrasco M. A., Maniatis T. The microRNA miR-124 promotes neuronal differentiation by triggering brain-specific alternative pre-mRNA splicing // Mol. Cell.-2007.-27, N 3.-P. 435-448.

141. Hengst $U$., Jaffrey $S$. R. Function and translational regulation of mRNA in developing axons // Semin. Cell Develop. Biol.-2007.-18, N 2.-P. 209-215.

142. Ramkissoon S. H., Mainwaring L. A., Ogasawara Y., Keyvanfar K., McCoy I. P., Sloand E. M., Kajigaya S., Young $N$. $S$. Hematopoietic-specific microRNA expression in human cells // Leuk. Res.-2006.-30, N 5.-P. 643-647.

143. Nervi C., Fazi F., Rosa A., Fatica A., Bozzoni J. Emerging role for microRNAs in acute promyelocytic leukemia // Curr. Top. Microbiol. Immunol.-2007.-313.-P. 73-84.

144. Lawric C. H. MicroRNAs and haematology: small molecules, big function // Brit. J. Haematol.-2007.-137, N 6.-P. 503-512.

145. Grivna B. T., Pyhtila B., Lin H. MIWI associates with translational machinery and PIWI-interacting RNAs (piRNAs) in regulating spermatogenesis // Proc. Nat. Acad. Sci. USA.-2006.-103, N 36.-P. 13415-13420.

146. Cobb B. S., Hertweck A., Smith J., O'Connor E., Graf D., Cook T., Smale S. T., Sakaguchi S., Zivescy F. G., Fisher A. $G$., Merkenshlager $M$. A role for Dicer in immune regulation // J. Exp. Med.-2006.-203, N 11.-P. 2519-2527.

147. Dahlberg J. E., Lund E. Micromanagement during the innate immune response // Sci. STKE.-2007.-387.-pe25.

148. Thai T. H., Calado D. P., Casola S., Ansel K. M., Xiao C., Xue Y., Murphy A., Frendewey D., Valenzuela D., Kutok J. L., Schmidt-Supprian M., Rajewsky N., Yancopoulos G., Rao A., 
Rajewsky $K$. Regulation of the germinal center response by microRNA-155 // Science.-2007.-316, N 5824.-P. 604-608.

149. Rodriguez A., Vigorito E., Clare S., Warren M. V., Couttet P., Soond D. R., van Dongen S., Grocock R. J., Das P. P., Miska E. A., Vetrie D., Okkenhaug K., Enright A. J., Dougan G., Turner M., Bradley A. Requirement of bic/microRNA-155 for normal immune function // Science.-2007.-316, N 5824.-P. 608-614.

150. Hobert $O$. miRNA play a tune // Cell.-2007.-131, N 1.P. 22-24.

151. Wu H., Neilson J. K., KumarP., Manocha M., Shankar P., Sharp P. A., Manjunath N. miRNA profiling of naive, effector and memory CD8 cells // PLoS ONE.-2007.-2, N 10.-e 1020 .

152. Boutz P. L., Chawla G., Stoilov P., Bloch D. L. MicroRNAs regulate the expression of the alternative splicing factor nPTB during muscle development // Genes Develop.-2007.-21, N 1.-P. 71-84.

153. Brueckner B., Stresemann C., Kuner R., Musch T., Meister M., Sultmann H., Lyko F. The human let-7a-3 locus contains epigenetically regulated microRNA gene with oncogenic function // Cancer. Res.-2007.-67, N 4.-P. 1419-1423.

154. Lujambio A., Roperos S., Ballestar E., Fraga M. F., Cerrato C., Setein F., Gasado S., Suarez-Gauthier A., Sanchez-Cespedes M., Gitt A., SpiteriI., Dass P. P., Caldas C., Miska E., Esteller M. Genetic unmasking of an epigenetically silenced microRNA in human cancer cells // Cancer Res.-2007.-67, N4.-P. 1424-1429.

155. Huppi K., Volfovsky N., Mackiewicz M., Runfola T., Jones T. L., Martin S. E., Stephens R., Caplen N. J. MicroRNA and genomic instability // Semin. Cancer Biol.-2007.-17, N 1.P. 65-73.

156. Saetrom P., Snove O. Jr., Rossi J. J. Epigenetics and microRNAs // Pediats. Res.-2007.-61, N 5, pt 2.-17R-23R.

157. Krutzfeldt J., Stoffel M. MicroRNAs: a new class of regulatory genes affecting metabolism // Cell Metab.-2006.-4, N 1.-P. 9-12.

158. Mercey B. D., Jin P., Danner D. J. Human microRNA (miR 296) expression controls amount of branched chain alfaketoacid dehydrogenase complex in a cell // Hum. Mol. Genet.-2005.-14, N 22.-P. 3371-3377.

159. Esau C., Davi S., Murray S. F., Xu X. X., Pandey S. K., Pear M., Watts Z., Booten S. L., Graham M., McKay R., Subramaniam A., Propp S., Lollo B. A., Prier S., Bennett C. $F$., Bhanot $S$., Monia B. P. miR-122 regulation of lipid metabolism revealed by in vivo antisense targeting // Cell Metabol.-2006.-3, N 2.-P. 87-98.

160. Gauthier B. R., Wollheim C. B. MicroRNA: «ribo-regulators» of glucose homeostasis // Nat. Med.- 2006.-12.-P. $36-38$.

161. Chiou T. J., Aung K., Lin S. J., Wu C. C., Chiang S. F., Su C. $L$. Regulation of phosphate homeostasis by microRNA in Arabidopsis // Plant Cell.-2006.-18, N 2.-P. 412-421.

162. Uney J. B., Ligthman S. L. MicroRNAs and osmotic regulation // Proc. Nat. Acad. Sci. USA.-2006.-103, N 42.-P. $15278-15279$.

163. Liang $H$., $L i W$. H. MicroRNA regulation of human protein-protein interaction network // RNA.-2007.-13, N 9.-P. 1402-1408.

164. Duan R., Jin P. Identification of messenger RNAs and microRNAs associated with fragile $\mathrm{X}$ mental retardation protein // Meth. Mol. Biol.-2006.-342.-P. 267-276.
165. Care A., Catalucci D., Felicetti F., Bonci D., Addario A., Gallo P., Bang M. J., Segnalini P., Gu Y., Dalton N. D., Elia J., Latronico M. V., Neydal M., Autore C., Russo M. A., Dorn J. W., Ellingsen O., Ruiz-Lozano P., Peterson K. J., Croce C. M., Peschle C., Condorelli G. MicroRNA-133 controls cardiac gypertrophy // Nat. Med.-2007.-13, N 5.- P. 613618.

166. Thum T., Galuppo P., Wolf C., Fiedler J., Kneitz S., van Zaake L. W., Doevendans P. A., Mummery C. L., Borlak J., Haverich A., Gross C., Engelhardt S., Erti G., Bauersachs J. MicroRNAs in the human heart: a clue to fetal gene reprogramming in heart failure // Circulation.-2007.-116, N 3.-P. 258-267.

167. Xu C., Lu Y., Pan Z., Chu W., Luo X., Lin H., Xiao J., Shan $H$., Wang Z., Yang B. The muscle-specific microRNAs miR-1 and miR-133 produce opposing effects on apoptosis by targeting HSP 60, HSP 70 and caspase-9 in cardiomyocytes // J. Cell Sci.-2007.-120, Pt 17.-P. 3045-3052.

168. Jeyaseelan K., Herath W. B., Armugan A. MicroRNAs as therapeutic targets in human diseases // Exp. Opin Ther. Targets.-2007.-11, N 8.-P. 1119-1129.

169. Van Rooij E., Olson E. N. MicroRNAs: powerful new regulators of heart disease and provocative therapeutic // J. Clin. Invest.-2007.-117, N 9.-P. 2369-2376.

170. Sayed D., Hong C., Chen I. Y., Lypowy J., Abdellatif M. MicroRNAs play an essential role in the development of cardiac hypertrophy // Circ. Res.-2007.-100, N 3.P. 416-424.

171. O'Connel R. M., Taganov K. D., Boldin N. P., Cheng G., Baltimor D. MicroRNA-155 is induced during the macrophage inflammatory response // Proc. Nat. Acad. Sci. USA.-2007.-104, N 5.-P. 1604-1609.

172. Rane S., Sayed D., Abdellatif M. microRNA with a macrofunction // Cell Cycle.-2007.-6, N 15.-P. 1850-1855.

173. Wu W., Sun M., Zou G. M., Chen J. MicroRNA and cancer: current status and prospective// Int. J. Cancer.-2007.-120, N 5.-P. 953-960.

174. Lee E. J., Gusev Y., Jiang J., Nuovo G. J., Lermer M. R., Frankel W. L., Morgan D. L., Postier R. G., Brackett D. J., Schmittgen T. D. Expression profiling identifies microRNA signature in pancreatic cancer // Int. J. Cancer.-2007.-120, N 5.-P. 1046-1054.

175. Xu W., Zi Y. Y. MicroRNA gene expression in malignant lymphoproliferative disorders // Clin. Med. J.-2007.-120, N 11.-P. 996-999.

176. Lawrie C. H. MicroRNA expression in lymphoma // Exp. Opin. Biol. Ther.-2007.-7, N 9.-P. 1363-1374.

177.Giannakakis A., Coukas G., Hatzigeorgion A., Sandaltzoupoulos R., Zhang L. miRNA genetic alterations in human cancers // Exp. Opin. Biol. Ther.-2007.-7, N 9.P. $1375-1386$.

178. Sabramanian S., Lui W. O., Lee C. H., Espinosa I., Nielsen T. O., Heinrich M. C., Corless C. I., Fire A. Z., Van de Rign $M$. MicroRNA expression signature of human sarcomas // Oncogene.-2007.-Oct. 8 [ Epub].

179. Blenkizon C., Goldstein L. D., Thorne N. P., Spiteri I., Chin S. F., Dunning M. J., Barbosa-Morais N. L., Teschendorff A. E., Green A. R., Ellis I. O., Tavare S., Caldas C., Miska E. A. MicroRNA expression profiling of human breast cancer identifies new markers of tumour subtype // Genome Biol.-2007.-8, N 10.-R214. 
180.Wurdinger T., Costa F. F. Molecular therapy in the microRNA era // Pharmacogenomics J.-2007.-7, N 5.P. 297-304

181. Yeung M. L., Bennasser Y., Jeang K. T. MiRNAs in the biology of cancers and viral infection // Curr. Med. Chem.-2007.-14, N 2.-P. 191-197.

182. Osada H., Takahashi T. MicroRNAs in biological processes and carcinogenesis // Carcinogenesis.-2007.-28, N 1.P. 2-12.

183. Wijnhoven B. P., Michael M. L., Watson D. I. MicroRNA and cancer // Brit. J. Surg.-2007.-94, N 1.-P. 23-30.

184. Porkka K. P., Pfeiffer M. J., WalteringK. K., Vessella R. L., Tammela T. L., Visacorpi T. MicroRNA expression profiling in prostate cancer // Cancer Res.-2007.-67, N 13.-P. 61306135.

185. Jay C., Nemunaitis J., Chen P., Fulgham P., Tong A. W. MiRNA profiling for diagnosis and prognosis of human cancer // DNA Cell Biol.-2007.-26, N 5.-P. 293-300.

186. Hernando E. MicroRNAs and cancer: role in tumorigenesis, patient classification and therapy // Clin. Trans. Oncol.-2007.-9, N 3.-P. 155-160.

187. Zhang $W$. , Dalberg J. E., Tam $W$. MicroRNAs in tumorigenesis: a primer // Am. J. Pathol.-2007.-171, N 3.P. 728-738.

188. Voorhoeve P. M., Agami R. Classifying microRNAs in cancer: the good, the bad and the ugly // Biochim. et Biophys. Acta.-2007.-1775, N 2.-P. 274-282

189. Calin G. A., Pekarsky Y., Croce C. M. The role of microRNA and other non-coding RNA in the pathogenesis of chronic lymphocytic leukemia // Best Pract. Res. Clin. Haematol.2007.-20, N 3.-P. 425-437.

190. Ma. L., Teruya-Feldstein J., Wienberg R. A. Tumour invasion and metastasis initiated by microRNA-10b in breast cancer // Nature.-2007.-449, N 7163.-P. 682-688.

191. Matsutara H., Takeuchi T., Nishikawa E., Yanagisawa K., Hayashuita Y., Ebi H., Yamada H., Suzuki M., Nagino M., Nemura Y., Osada H., Takahashi T. Apoptosis induction by antisense oligonucleotides against miR-17-5p and miR-20a in lung cancer overexpressing miR-17-92 // Oncogene.2007.-26, N 41.-P. 6099-6105.

192. Corsten M. F.,Miranda R., Kasmieh R., Krichevsky A. M., Weissleder R., Shah K. MicroRNA-21 knockdown disrupt glioma in vivo and displays synergistic cytotoxicity with neural precursor cell delivered S-TRAIL in human gliomas // Cancer Res.-2007.-67, N 19.-P. 8994-9000

193. Bottoni A., Zatelli M. C., Ferracin M., Tagliati F., Piccin D., Vignali C., Calin G. A., Negrini M., Croce C. M., Degli U. E. $C$. Identification of differentially expressed microRNA by microarray: a possible role for microRNA genes in pituitary adenomas // J. Cell Physiol.-2007.-210, N 2.-P. 370-377.

194. Pallante P., Visone R., Ferracin M., Ferraro A., Berlingierri M. T., Troneone G., Chippetta G., Lin C. G., Santoro M., Negrini M., Croce C. M., Fusko A. MicroRNA deregulation in human thyroid papillary carcinomas // Endocrinol. Relat. Cancer.-2006.-13, N 2.-P. 497-508

195. Volinia S., Calin G. A., Liu C. G., Ambs S., Cimmino A., Petrocca F., Visone R., Jorio M., Roldo C., Ferracin M., Prueitt R. L., Yanaihara N., Lanza G., Searpa A., Vecchione A., Negrini M., Harris C. C., Croce C. M. A microRNA expression signature of human solid tumors defines cancer gene targets // Proc. Nat. Acad. Sci. USA.-2006.-103, N 7.-P. 2257-2261.
196. Liu W., Mao S. Y., Zhu W. Y. Impact of tiny miRNAs on cancer // World J. Gastroenterol.-2007.- 13, N 4.-P. 497502.

197. Nairz K., Roffig C., Rintelen F., Zdobnov E., Moser M., Hafen $E$. Overgrowth caused by misexpression of a microRNA with dispensable wild-type function // Develop. Biol.-2006.-291, N 2.- P. 314-324.

198. Weber F., Teresi R. F., Broelsch C. E., Frilling A., Eng C. A limited set of human microRNA is deregulated in follicular thyoid carcinoma // J. Clin. Endocrinol. Metab.-2006.-91, N 9.-P. 3584-3591.

199. Lee Y. S., Dutta A. MicroRNA: small but potent oncogenes or tumor suppressors // Invest. Drugs.-2006.-7, N 6.-P. 560564.

200. Tam W., Dahlberg J. I. MiR $155 /$ BIC as an oncogenic microRNA // Genes Chromosom. Cancer.-2006.-45, N 2.P. 211-212.

201. Hayashita Y., Osada H., Tatematsu Y., Yamada P., Yanagisawa K., Tomida S., Yatabe Y., Kawahara K., Sekido $Y$., Takahashi T. A polycystronic microRNA cluster, miR-17-92, is overexpressed in human lung cancer and enhances cell proliferation // Cancer Res.-2005.-65, N 21.-P. 9628-9632.

202. Voorhoeve P. M., Le Sage C., Schrier M., Gillis A. J., Stoop H., Nagel R., Liu J. P., Van Duijse J., Drost J., Griekspoor A., Zlotozynski E., Yabuta N., De Vita G., Nojima H., Looijenga L. H., Agami R. A genetic screen implicates miRNA-372 and miRNA-373 as oncogenes in testicular germ cell tumor // Cell.-2006.-124, N 6.-P. 1169-1181.

203. Akao Y., Nakagawa Y., Naoe T. MicroRNAs 143 and 145 are possible common onco-microRNAs in human cancer // Oncol. Rep.-2006.-16, N 4.-P. 845-850.

204. Yu S. L., Chen H. Y., Yang P. S., Chen J. J. Unique microRNA signature and clinical outcome of cancers // DNA Cell Biol.-2007.-26, N 5.-P. 283-292.

205. Esquela-Kerscher A., Slaek F. J. Oncomirs - microRNAs with a role in cancer // Nat. Rev. Cancer.-2006.-6.-P. 259269.

206. Kent O. A., Mendell J. T. A small piece in the cancer puzzle: microRNAs as tumor suppressors and oncogenes // Oncogene.-2006.-25, N 46.-P. 6188-6196.

207. Hammond S. M. MicroRNAs as oncogene // Curr. Opin Genet. Develop.-2006.-16, N 1.-P. 4-9.

208. Hwang H. W., Mendel J. T. MicroRNA in cell proliferation, cell death, and tumorigenesis // Brit. J. Cancer.-2006.-94, N 6.-P. 776-780.

209.Janott G., Simard M. J. Tumour-related microRNAs functions in Caenorhabditis elegans // Oncogene.-2006.-25, N 46.-P. 6197-6201.

210. Calin G. A., Croce C. M. Genomics of chronic lymphocytic leukemia microRNAs as ew players with clinical significance // Semin. Oncol.-2006.-33, N 2.-P. 167-173.

211. Hossain A., Kuo M. T., Saunders G. F. Mir 17-5p regulates breast cancer cell proliferation by inhibiting translation of ALB1mRNA // Mol. Cell Biol.-2006.-26, N 21.P. 8191-8201.

212.Hwang H. W., Mendell J. T. MicroRNAs in cell proliferation, cell death, and tumorigenesis // Brit. J. Cancer.-2007.-96, suppl.-R40-44.

213.Tricoli J. V., Jacobson J. W. MicroRNA: potential for cancer detection, diagnosis, and prognosis // Cancer Res.-2007.-67, N 10.-P. 4553-4555. 
214. Perron M. P., Boissonneault V., Gobeil L. A., Ouellet D. L., Provost $P$. Regulatory RNAs: future perspectives in diagnosis, prognosis, and individualized therapy // Meth. Med. Biol.-2007.-163.-P. 311-326.

215. Negrini M., Feracin M., Sabbioni S., Croce C. M. MicroRNAs in human cancer: from research to therapy // J. Cell Sci.-2007.-120, pt 11.-P. 1833-1840.

216. Esau C. C., Monia B. P. Therapeutic potential for microRNAs // Adv. Drug Deliv. Rev.-2007.-59, N 2-3.P. 101-114.

217. Jeyaseelan K., Herath W. B., Armugam A. MicroRNAs as therapeutic targets in human disease // Exp. Opin. Ther. Targets.-2007.-11, N 8.-P. 1119-1129.

218.Bandres E., Agirre $X$., Ramirez $N$., Zarate $R$., Garcia-Fonsillas J. MicroRNAs as cancer players: potential clinical and biological effects // DNA Cell Biol.-2007.-26, N 5.-P. 273-282.

219. Krutzfeldt J., Rayewsky N., Braich R., Rajeev K. G., Tusch T., Manoharan M., Stoffel M. Silencing of microRNAs in vivo with «antagomirs»// Nature.-2005.-438, N 7068.-P. 685689.

220. Orom U. A., Kauppinen J., Lund A. H. LNA-modified oligonucleotides mediate specific inhibition of microRNA function // Gene.-2006.-10, N 372.-P. 137-141.

221. Naguibneva J., Ameyar-Zazona M.,Nonne N., Polesskaya A., Ait-Si-Ali S., Groisman R., Sonidi M., Pritchard L. L., Harol-Bellan A. An LNA-based loss-of-function assay for microRNAs // Biomed. Pharmacother.-2006.-60, N 9.P. 633-638

222. Tsuda N., Ishiyama S., Li Y., Ioannides C. G., Abbruzzese J. L., Chang D. L. Synthetic microRNA designed to target glioma-associated transcription factor inhibits division and induces late apoptosis in pancreatic tumor cells // Clin. Cancer Res.-2006.-21, N 21.-P. 6557-6564.

223. Davis S., Lollo B., Fraier S., Esau C. Improved targeting of miRNA with antisense oligonucleotides // Nucl. Acids Res.-2006.-34, N 8.-P. 2294-2304.

224. Mattes J., Yang M., Foster P. S. Regulation of microRNA by antagomirs: a new class of pharmacological antagomirs for the specific regulation of gene function? // Am. J. Respir. Cell Mol. Biol.-2007.-36, N 1.-P. 8-12.

225. Snove O. N., Rossi J. J. Toxisity in mice expressing short hairpin RNAs gives new insight intoRNAi // Genome Biol.-2006.-7, N 8.-P. 231.

226. Grimm D., Streetz K. L., Jopling C. L., Storm T. A., Pandey K., Davis C. R., Marion P., Salazar F., Kay M. A. Fatality in mice due to oversaturation of cellular microRNA/short hairpin RNA pathways // Nature.-2006.-441, N 7092.P. 537-541.

227. John M., Constien R., Akinc A., Goldberg M., Moon Y.-A., Spranger M., Hadwiger P., Soutschek J., Vornlocher H.-P., Manohacan M., Stoffel M., Langer R., Anderson D. G., Horton G. D., Koteliansky V., Bumcrot D. Effective RNAi-mediated gene silencing without interruption of the endogenous microRNA pathway // Nature.-2007.-449.P. 745-747.

228. Jain K. K. Commercial potential of RNAi // Mol. Biosyst.-2006.-2.-P. 523-526.

UDC 577.21:615.01:616-092

Received 14.02.07 